\title{
Electrochemical Analysis of Some Biodegradable Mg-Ca-Mn Alloys
}

\author{
BOGDAN OPRISAN 1 , DECEBAL VASINCU ${ }^{2 *}$, STEFAN LUPESCU $^{3 *}$, CORNELIU MUNTEANU $^{3}$, \\ BOGDAN ISTRATE ${ }^{3 *}$, DIANA POPESCU ${ }^{3}$, CATALIN PLESEA CONDRATOVICI ${ }^{4}$, \\ ALINA RAMONA DIMOFTE ${ }^{4}$, KAMEL EARAR ${ }^{4}$ \\ ${ }^{1}$ Gr.T. Popa Medicine University of Iasi, Faculty of General Medicine, 16 University Str., Iasi, Romania \\ ${ }^{2}$ University of Medicine and Pharmacy Grigore T. Popa, Faculty of DentalMedicine, 16 Universitatii Str. 700115, Iasi, \\ Romania \\ ${ }^{3}$ Gheorghe Asachi University of Iasi, Faculty of Mechanical Engineering Department, 43 DimitrieMangeron Str., 700050, \\ Iasi \\ ${ }^{4}$ University „Dunărea de Jos”of Galați, Faculty of Medicine and Pharmacy, 35 Al. I. Cuza Str., Galati, Romania
}

\begin{abstract}
The potential benefits of magnesium (Mg) over the other non-resorbable biomaterials, especially for orthopedic applications, are obvious. When fully realized, functional bioresorbable implants based on Mg alloys offer the mechanical advantages of a metal combined with the degradable and biological advantages of polymers and biomaterials. [1]In this article we obtained aMg-based prelate alloyed with $\mathrm{Ca}$ and Mn. It is known that Mn helps to refine the alloy's microstructure, which adds to the elasticity of the material. Surface morphology was performed using the optical microscope and the electron microscope while the mechanical tests were performed using the tribometer. Also, the electrochemical tests were executed in the ringer solution. It has been mentioned that the electrochemical resistance is quite low. This study was conducted to determine the corrosion resistance of $\mathrm{Mg}-\mathrm{Ca}-\mathrm{Mn}$ alloys. It has been demonstrated that the addition of $\mathrm{Mn}$ refines the microstructure, increases the modulus of elasticity but does not have a qualitative resistance to corrosion.Also, the hardness of the material is quite low in comparison to other pre-alloys of $\mathrm{Mg}$.
\end{abstract}

Keywords:Surface morphology,mechanical tests, electrochemical tests

The use of other magnesium alloys is restricted by some limitations, such as corrosion resistance and low creep resistance [1-2]. A number of studies are focused on corrosion behaviour towards others of $\mathrm{Mg}$, however they are limited on microstructuralcharacteristic and corrosion behavior compared to steels. In addition, there is a good biocompatibility and in-vivo safety [24]. However, there is a major problem for alloys of $\mathrm{Mg}$, which is by their low corrosion resistance, which hinders their use on the market. It's applications may be limited, especially when exposed to aggressive environments such as marine salts. The main reason is [4-7]: (i) the negative electrochemical potential of magnesium ($2.37 \mathrm{~V}$ (vs. SHE)), which is lower among the industry metals. One of the most important elements for the human body is $\mathrm{Mg}$ which is part of the bone tissue molecular structure and it is involved in several metabolic processes [3]. In recent years, many rare earth elements (REs) have been added to increase mechanical properties, to prevent oxidation and increase corrosion resistance caused by the purifying effect of these elements in the alloy melt and the role of the phases they contain, which are attached to the grain boundaries, [8-10]. The cost of these elements is relatively high and stable, which weakens the potential for industrial applications of $\mathrm{Mg}$ alloys containing RE[22]. Therefore, new RE- Mg alloys with exceptional mechanical properties and corrosion resistance are required. Certainly, alloy characteristics were obtained by adding calcium (Ca) in $\mathrm{Mg}$ alloys as a micro-alloying element[12-14]. Han [15] reported that $\mathrm{Mg}-\mathrm{Al}-\mathrm{Ca}$ alloys have aremacable strength and elasticity modulus due to the solid Ca solution. Cao [16] and Jeong [17] found that the corrosion resistance of the $\mathrm{Mg}$ alloy can be improved by the addition of $\mathrm{Ca}$. However, the range of Ca content in the aforementioned studies is relatively small. $\mathrm{Mn}$ can improve the purity of $\mathrm{Mg}$ alloys by reducing the impurity content of the iron and the alloy silicone, which leads to good corrosion resistance [11]. It has been proven that after alloying $\mathrm{Mg}$ with different alloys, the increase of resistance is noticeable. In contrast, manganese (Mn) shows no toxic effect in the physiological environment and plays a major role in activating the multiple enzyme system[23]. The addition of Mnhas the potential to refine further the grains and improve the recrystallization temperature of $\mathrm{Mg}$ alloys. Earlier studies have shown that a small amount of $\mathrm{Mn}$ in $\mathrm{Mg}$ alloys can remove intractable impurities such as $\mathrm{Fe}$ and heavy metal elements forming intermetallic phases and thus improve corrosion characteristics [18,19], but the effect of $\mathrm{Mn}$ on $\mathrm{Mg}$ alloys has not yet been more thoroughly researched.

*email: decebal.vasincu@umfiasi.ro,-lupescustefan@ymail.com; bogdan_istrate1@yahoo.com 
We also reported that the distribution coefficient $(\mathrm{k})$ of Mn (1.1) means that it does not accumulate on the solid / liquid side, and Mn can be a solute within the primary dendrites without forming compounds containing Mn. The Mn solute in dendrites changes the surface film composition of $\mathrm{Mg}$ alloys, which also affects the exchange density of the reaction current of the evolution of the hydrogen cathode [20]. The corrosion behavior of the aqueous solution of $\mathrm{Mg}$ alloys is the result of an electrochemical process in which $\mathrm{Mg}$ ionizes anodic, with the predominant hydrogen evolution of the cathodic reaction based on hydrogen. Refining the microstructure with the addition of $\mathrm{Mn}$ is beneficial for the alloy[21].

In this paper, we systematically investigated the microstructure and, in particular, the corrosion resistance of some alloys in the $\mathrm{Mg}_{-0.5} \mathrm{Ca}-\mathrm{xMn}$ system. This study has been executed with the increase of $\mathrm{Mn}$ content in the alloy.

Table 1 presents the quality certificate of $\mathrm{MgCa}$ and $\mathrm{MgMn}$ ingots, sent by the company from where they were purchased, Hunan China Co.

Table 1

CERTIFICATE OF QUALITY-HUNAN CHINA Co.

\begin{tabular}{|l|l|l|l|l|l|l|}
\hline Alloys & $\mathrm{Mg} / \mathrm{F}$ & $\mathrm{Fe}$ & $\mathrm{Ni}$ & $\mathrm{Cu}$ & $\mathrm{Si}$ & $\mathrm{Al}$ \\
\hline Pure $\mathrm{Mg}$ & $\mathrm{Mg}(99 \%)$ & - & - & - & - & - \\
\hline $\mathrm{Mg} 15 \mathrm{Ca}$ & $\mathrm{Ca}(15.29 \%)$ & $0.004 \%$ & $0.001 \%$ & $0.003 \%$ & $0.013 \%$ & $0.011 \%$ \\
\hline $\mathrm{Mg} 3 \mathrm{Mn}$ & $\mathrm{Mn}(2.79 \%)$ & $0.002 \%$ & $0.004 \%$ & $0.001 \%$ & $0.005 \%$ & $0.035 \%$ \\
\hline
\end{tabular}

\section{Experimental part}

\section{Materials and methods}

The alloys $\mathrm{Mg}_{-0.5} \mathrm{Ca}_{-0.5} \mathrm{Mn}, \mathrm{Mg}_{-0.5} \mathrm{Ca}_{-1} \mathrm{Mn}, \mathrm{Mg}_{-0.5} \mathrm{Ca}_{-1.5} \mathrm{Mn}, \mathrm{Mg}_{-0.5} \mathrm{Ca}_{-2} \mathrm{Mn}, \mathrm{Mg}_{-0.5} \mathrm{Ca}_{-3} \mathrm{Mn}$ were made from high purity compounds, the chromium composition is presented in table 1 . The melting and alloying operations were carried out in a graphite crucible under a gas mixture (Ar) at $750 \mathrm{C}$. The melting was maintained for $30 \mathrm{~min}$ at $750 \mathrm{C}$ to ensure that all the required alloying elements were dissolved in the molten alloy.Afterwards, the crucibles were left to cool, followed by the removal of the alloys from crucibles and thenrefined into the shape of a bar.

The bars were cut into pills of $12 \mathrm{~mm}$ in diameter and the frame of $4 \mathrm{~mm}$ thick, sanded with abrasive paper up to $2500 \mathrm{SiC}$ and finished with alumina suspension, the samples were left to dry in the open air and chemically attacked to observe the microstructure of the surfaces.

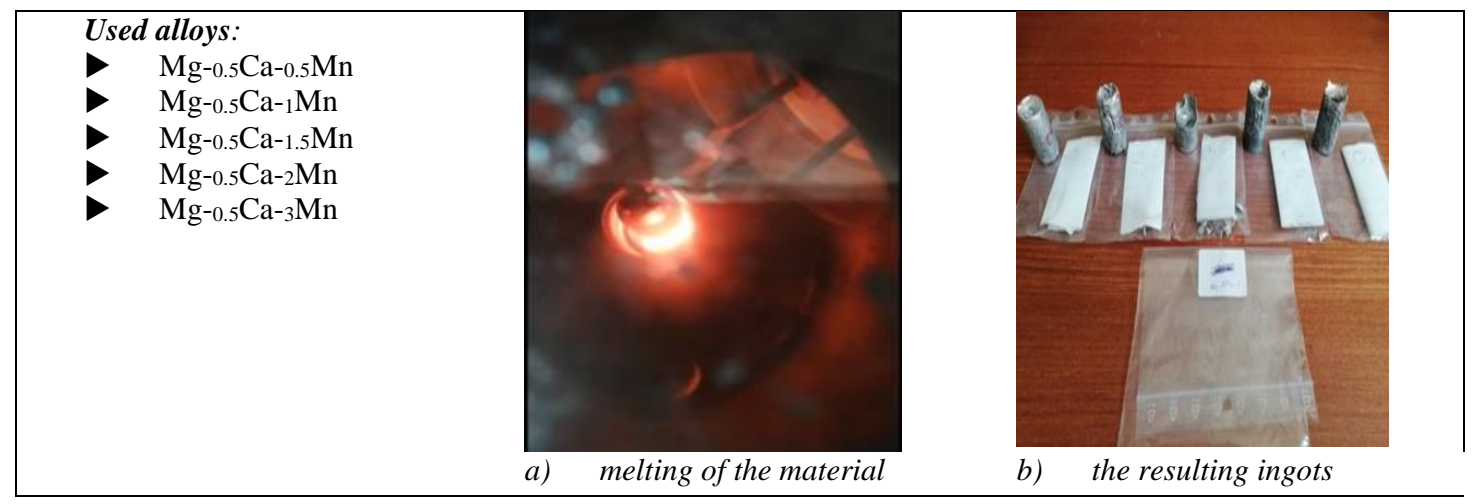

Fig. 1

\section{Microstructure}

The microstructure of the cast alloys was observed using an optical microscope. The intermetallic secondary phases of the cast alloys were analyzed by $\mathrm{X}$-ray diffraction (XRD) using mono-chromatic $\mathrm{Cu}-\mathrm{K}($ alpha) radiation.

\section{Electrochemical testing}

For the corrosion test, a Volta Lab 21 potentiostat was used. The corrosion current determined in this way represents the corrosion current that appears at the metal / medium interface when the metal is immersed in the solution and can be measured directly by electrochemical methods. To calculate the corrosion rate of an alloy immersed in a corrosive environment, it is necessary to know the density of the instantaneous current that is determined by the polarized resistance method. A cell containing three electrodes was used: platinum auxiliary electrode, saturated calomel electrode and working electrode. The measurements were made at $20^{\circ} \mathrm{C}$ and the electrolyte was naturally aerated, the linear polarization curves were recorded at a scanning speed of the electrode potential of $1 \mathrm{mV} / \mathrm{s}$ and the cyclical polarization curves were performed at a scanning speed of $10 \mathrm{mV} / \mathrm{s}$.

This method is used to determine the corrosion current at the corrosion potential of the metal or alloy, from the linear polarization curve obtained for relatively small overvoltages. The corrosion current thus determined is actually the 
corrosion current that appears at the metal / corrosive medium interface when the metal is immersed in the solution and cannot be measured directly by electrochemical methods. This is actually an instant corrosion current.

\section{$\underline{\text { Surface analysis }}$}

The cross sections of the samples were also prepared by focusing the focused ion beam (FIB) to analyze their surface films by high resolution transmission electron microscopy (NU AM FOLOSIT ASTA-refaci) (Quanta 3D scanning microscope) and energy dispersion X-ray spectroscopy ( EDS).

\section{Results and discussion}

\section{Microstructure and XDR analysis}

Optical micrographs for $\mathrm{Mg}_{-0.5} \mathrm{Ca}-\mathrm{xMn}$ alloys are shown in Figure 1. It was observed that by increasing the quantity of $\mathrm{Mn}$, the microstructure is refined, and the particles of the second phase that contain Ca tend to distribute in the interdendrite areas. It can be observed that the compound $\mathrm{Mg}_{2} \mathrm{Ca}$ is formed at the grain boundary of $\mathrm{Mg}$. All alloys showed $\alpha-$ $\mathrm{Mg}$ peaks. From the EDS analysis, the presence of other impurities such as $\mathrm{Cu}, \mathrm{Ni}$ and $\mathrm{Fe}$ can be explained by this impurity content of the alloy composition.

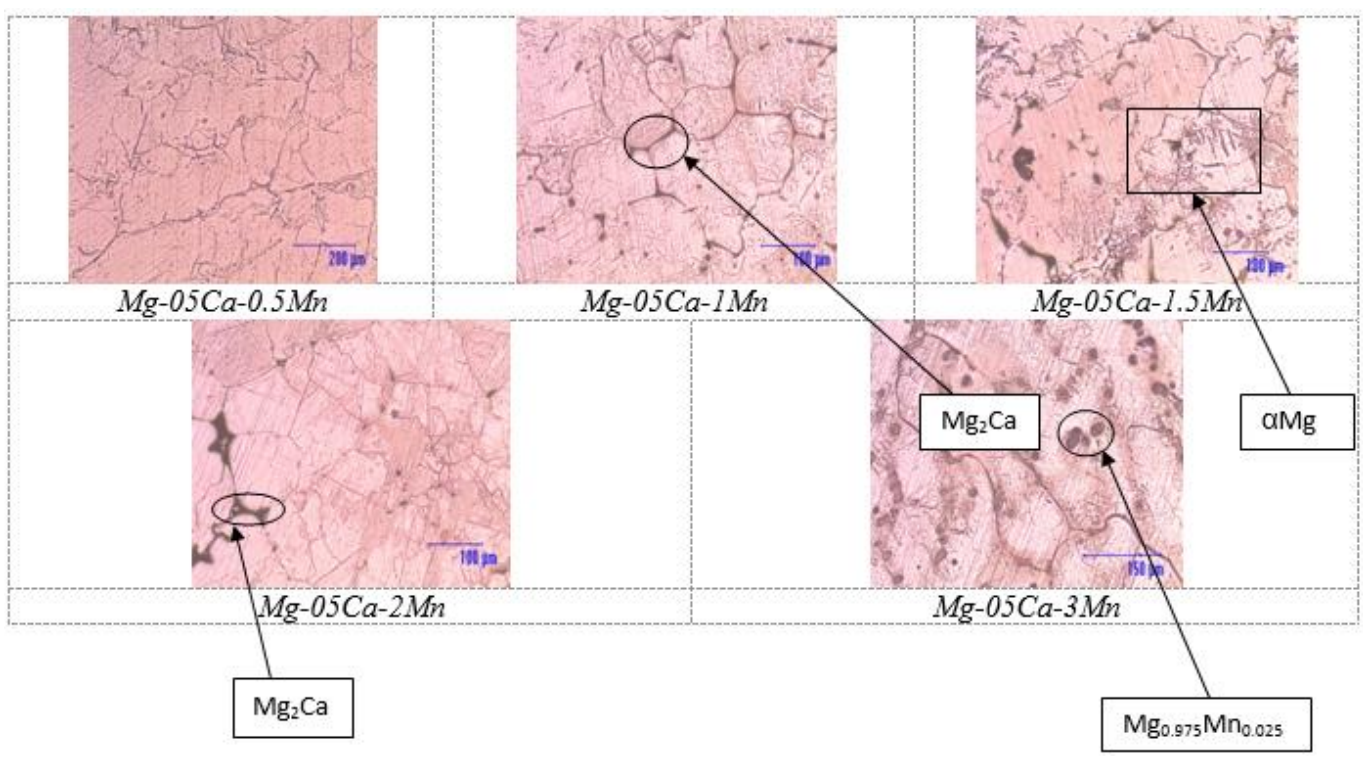

Fig. 2. Optical microstructures of Mg alloys

XRD analysis shows us three major phases: $\alpha-\mathrm{Mg}, \mathrm{Mg}_{2} \mathrm{Ca}$ and $\mathrm{Mg}_{0.975} \mathrm{Mn}_{0.025}$, the previously specified compounds resulting from the peaks of the graph in Figure 3. It is shown that $\mathrm{Mg}_{0.975} \mathrm{Mn}_{0.025}$ has the same hexagonal crystallographic structure as pure $\mathrm{Mg}$ and $\mathrm{Mg}_{2} \mathrm{Ca}$ has a monoclinic structure. All alloys showed $\alpha-\mathrm{Mg}$ peaks.

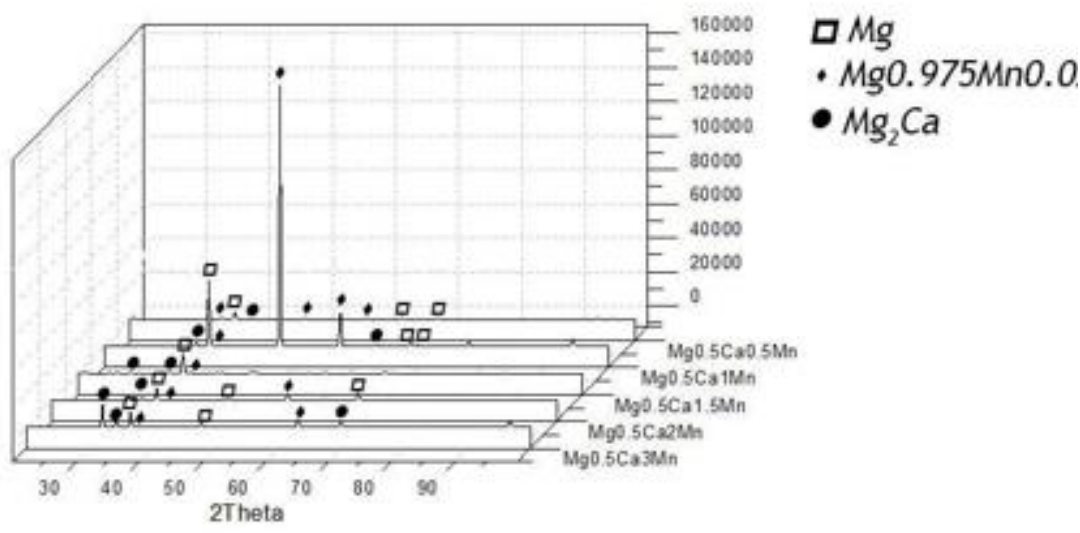

Fig. 3. XRD analysis of experimental alloys $\mathrm{Mg}-0.5 \mathrm{Ca}-\mathrm{xMn}$

\section{Electrochemical testing}

In the table 3 are presented the parameters obtained from the electro-corrosion resistance tests of the experimental alloys $\mathrm{Mg}_{0.5} \mathrm{Cax}(\mathrm{x}=0.5 ; 1 ; 1.5 ; 2$ and $3 \mathrm{wt} . \%) \mathrm{Mn}$, tests performed in SBF solution. Since magnesium alloys eliminate high amounts of gas from the surface of the samples, gas bubbles are still forming. These gas bubbles were removed by 
using a magnetic stirrer that operated at a relatively slow rate of agitation of the electrolyte solution. At each test, the fresh electrolyte solution was changed. Chemical composition of immersion solution is presented in table 2 .

Table 2

CHEMICAL COMPOSITION OF IMMERSION SOLUTION

\begin{tabular}{|c|c|c|c|c|c|c|c|c|}
\hline $\begin{array}{c}\text { Chemical Composition (Ions) } \\
\left(\mathrm{mmol} / \mathrm{dm}^{3}\right)\end{array}$ & $\mathbf{N a}^{+}$ & $\mathbf{K}^{+}$ & $\mathbf{M g}^{2+}$ & $\mathbf{C a}^{2+}$ & $\mathbf{C l}^{-}$ & $\mathbf{H C O}_{3}{ }^{-}$ & $\mathbf{H P O}_{4}{ }^{{ }^{2-}}$ & $\mathbf{S O}_{4}{ }^{{ }^{-}-}$ \\
\hline Simulated body fluid & 142 & 5 & 1.5 & 2.5 & 147.8 & 4.2 & 1 & 0.5 \\
\hline Human blood plasma & 142 & 5 & 1.5 & 2.5 & 103 & 27 & 1 & 0.5 \\
\hline
\end{tabular}

Table 3

PARAMETERS OBTAINED FROM THE ELECTRO-CORROSION RESISTANCE TESTS OF THE EXPERIMENTAL ALLOYS Mg ${ }_{0.5} \mathrm{Cax}(\mathrm{x}=0.5 ; 1 ; 1.5 ; 2$ AND 3wt.\%) $\mathrm{Mn}$

\begin{tabular}{|c|c|c|c|c|c|c|c|}
\hline Sample & $\begin{array}{l}\mathrm{E}_{0} \\
\mathrm{mV}\end{array}$ & $\begin{array}{l}\mathrm{ba} \\
\mathrm{mV}\end{array}$ & $\begin{array}{l}\mathrm{bc} \\
\mathrm{mV}\end{array}$ & $\underset{\substack{\mathrm{Rp} \\
\text { ohm.cm² }}}{2}$ & $\begin{array}{c}\text { Jcor } \\
\mu \mathrm{A} / \mathrm{cm}^{2}\end{array}$ & $\begin{array}{l}\text { Vcor } \\
\mathrm{mm} / \mathrm{an}\end{array}$ & $\begin{array}{c}\mathrm{OCP} \\
\mathrm{V}\end{array}$ \\
\hline Mg_Ca_0,5Mn & 1971.7 & 114.5 & -105.0 & 1.32 & 76.88 & 0.85 & -1.6 \\
\hline Mg_Ca_1Mn & 1755.1 & 174.1 & -170.9 & 1.21 & 23.52 & 0.56 & -1.66 \\
\hline $\mathrm{Mg} \_\mathrm{Ca} \_1,5 \mathrm{Mn}$ & 1695.7 & 160.2 & -172.8 & 1.17 & 23.21 & 0.56 & -1.56 \\
\hline Mg_Ca_2Mn & 1703.0 & 122.4 & -97.3 & 1.26 & 68.05 & 0.63 & -1.58 \\
\hline Mg_Ca_3Mn & 1761.0 & 178.3 & -185.7 & 1.22 & 23.44 & 0.55 & -1.55 \\
\hline
\end{tabular}

In all cases are observed in processing the presence of both types of reception for anodic and cathodic tea while the branches may have values close to the opposite sign. A larger difference is observed only under test conditions with $2 \%$ $\mathrm{Mn}$. The anodic branch is much larger than the cathodicand this fact may be a less pronounced passage of a metallic element while looking at it in others. With the exception of the cases with $0.5 \%$ and $2 \% \mathrm{Mn}$, similar corrosion rates with $0.56 \mathrm{~mm}$ per year were obtained. Electro-corrosion currents (jcor) confirm this behavior. The corrosion current is thus determined during the corrosion cure current, the interface of the metal / corrosive medium appears when it is metallic and is immersed in solutions and cannot be measured by the direct electrochemical method. This is actually an instantaneous corrosion current. The resistance of the polarization and other experimental ones are close to this one.

The Tafel variations show the similar behavior of the experimental alloys with a small differentiation of the potential of the $\mathrm{MgCaMn}$ alloy. The linear polarization resistance method is probably one of the most widespread applications of electrochemical measurements in the laboratory and is very well applied in the case of uniform (generalized) corrosion.

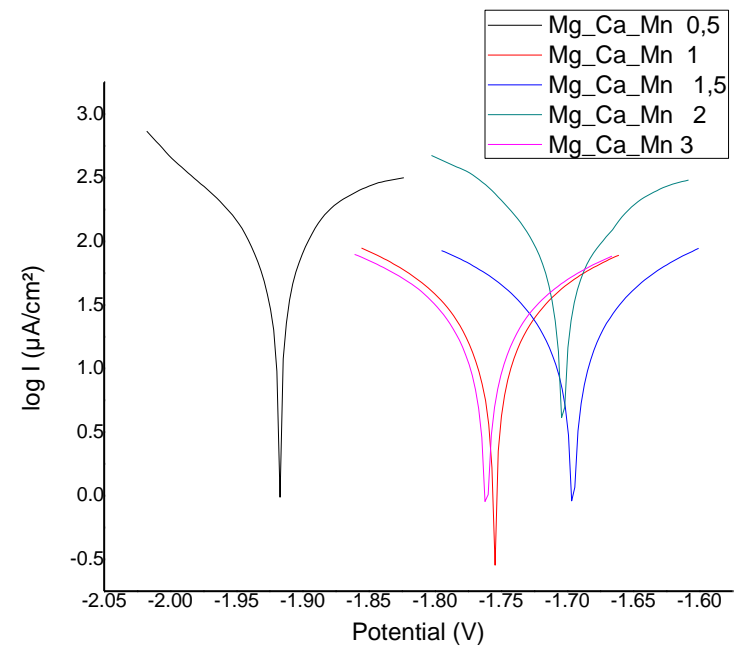

Fig. 4. Tafel diagrams of $\mathrm{Mg}-0.5 \mathrm{Ca}-\mathrm{xY}$-based experimental alloys

Figure 5 shows the cyclical curves characteristic of the experimental samples from the MgCaMn system. From the analysis of the cyclical polarization curves (cyclic voltamograms), one of them can obtain information regarding the type of electrochemical process that takes place at the electrode / environment interface (such as: generalized corrosion, localized corrosion, passivation, oxidation reductions of the solution species), evaluation characteristic potentials (corrosion potential, piercing potential, re-passivation potential, protection potential). 
The general appearance of the corrosion is of generalized corrosion more accentuated for the $\mathrm{Mg}_{0.5} \mathrm{Ca}_{2} \mathrm{Mn}(\mathrm{SCRIE}$ FORMULA) and MgCa1Mn samples with a larger loop given by the corrosion intensity. In both cases mentioned, with $1 \%$ and $2 \% \mathrm{Mn}$ respectively, the generalized corrosion is supported by many pitting corrosion zones which evolve very quickly and which, by combining their effects, it transforms in a very short time into generalized corrosion.

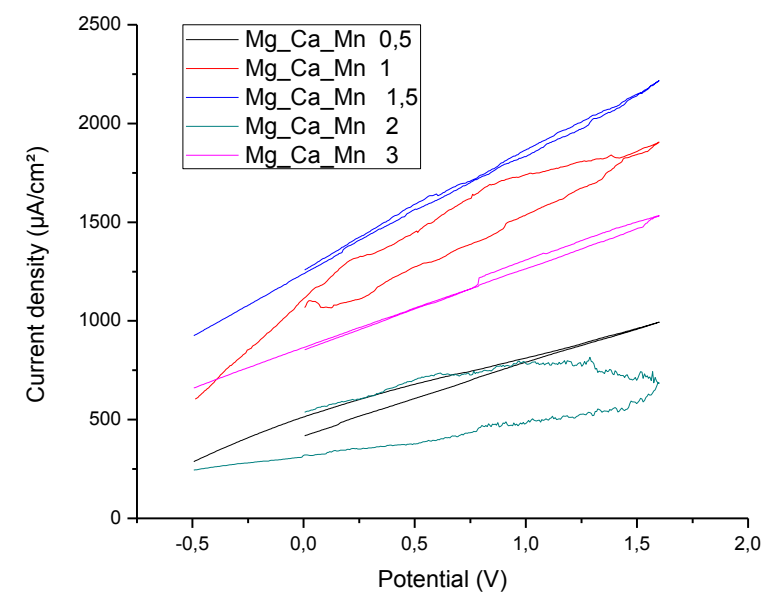

Fig. 5. Cyclic curves characteristic of the experimental samples from the $\mathrm{MgCaMn}$ system

\section{Surface analysisof corroded samples}

Figure 6 shows the SEM images after the 5000x magnification corrosion test, there are no traces of corrosion at points and the degradation occurs by oxidizing the surface layer of the alloy and detaching it from the substrate.

It is observed the identification of a smaller percentage of oxygen on the surface of the material compared tothesample $\mathrm{Mg}_{0.5} \mathrm{Ca}_{0.5} \mathrm{Mn}$ (6.6 comparedto $25 \%$ - Tab.2), also the quantities of salts are lower or equal to the chlorine-based compounds. Adding $1 \% \mathrm{Mn}$ increases the electro-corrosion resistance of the $\mathrm{MgCa}$ alloy and significantly reducing the amount of oxide on the surface compared to the behavior of the $\mathrm{Mg}_{0.5} \mathrm{Ca}_{0.5} \mathrm{Mn}$ sample, but, the best resistance to electrocorrosionisthe $\mathrm{Mg}_{0.5} \mathrm{Ca}_{3} \mathrm{Mn}$ alloyfollowedby $\mathrm{Mg}_{0.5} \mathrm{Ca}_{2} \mathrm{Mn}$.

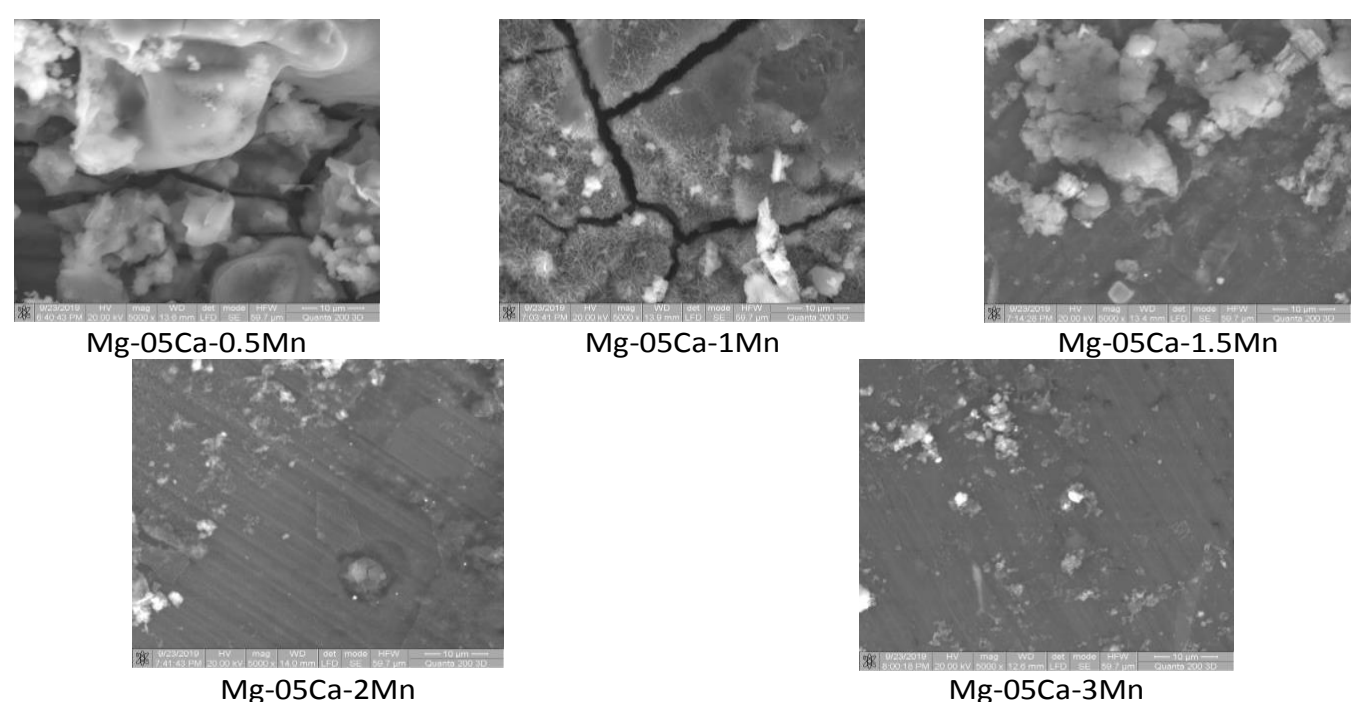

Fig. 6. SEM images of the surface of the material after the electro-corrosion test at 5000x magnification

\section{Conclusions}

Thisresearchshowsthat with the increase of the Mn content in the alloy, the microstructure is more refined thus showing an increase in the strength of the alloy.Following the results of X-ray diffraction tests, we can observe a series of $\mathrm{Mg}_{2} \mathrm{Ca}$ compounds having a monoclinic form and $\mathrm{Mg}$ and $\mathrm{Mg}_{0.975} \mathrm{Mn}_{0.025}$ having a hexagonal shape. On the morphology of the surface we can see that the compound $\mathrm{Mg}_{2} \mathrm{Ca}$ is formed at the boundary of $\mathrm{Mg}$ grains, and $\mathrm{Mg}_{0.975} \mathrm{Mn}_{0.025}$ are formed separately. 
Fromtheanalysis of the results recorded in the case of electro-corrosion resistance experiments it was observed that the highest corrosion rate is the alloy with $0.5 \% \mathrm{Mn}$ respectively $0.85 \mathrm{~mm} /$ year and the smallest alloy with $3 \%$ respectively $0.55 \mathrm{~mm} /$ year.The Tafel curves show close values of the ba and bc branches which represents a close activity for the two types of reactions, reduction and oxidation or anodic and cathodic, which take place at the contact between an alloy and an aqueous electrolyte environment.The cyclical polarization curves indicate for all samples a generalized surface corrosion more pronounced in the case of samples with 1 and $2 \%$ Mn respectively.The experimental alloys showed, in all cases, a combined corrosion between galvanic, intercrystallineandpointcorrosion.

The microstructuralsurfaceanalysis by SEM electron microscopy highlights a generalized surface corrosion that was observed with the formation of compounds on the surface of the materials in the electrolyte solution. Zonal traces of corrosion at points were also observed due to the inhomogeneities or inclusions that appear in the experimental alloys.

Acknowledgment: „,This work was supported by a grant of the Romanian Ministery of Research and Innovation, CCCDI - UEFISCDI, project number PN-III-P1-1.2-PCCDI-2017-0239 / 60PCCDI 2018, within PNCDI III”.

\section{References}

1. I. POLMEAR, Light Alloys, third ed., Arnold, London, UK, 1985.

2. K.U. KAINER, Magnesium - Alloys and Technology, Wiley VCH-Verlag Gmbh,

Weinheim, Germany, 2003.

3. P. TIAN, X. LIU, Surface modification of biodegradable magnesium and its alloys forbiomedical applications, Regen. Biomater. 2 (2015) 135151,https://doi.org/10.1093/rb/rbu013.

4.J.LIAO,M.HOTTA,Y.MORI,Improved corrosion resistance of ahigh-strengthMg-Al-Mn-Ca magnesium alloy made by rapid solidification powder metallurgy, Mater.Sci.Eng., A544(2012)10-20.

5.S.V.LAMAKA,D.HÖCHE,R.P.PETRAUSKAS,C.BLAWERT,M.L.ZHELUDKEVICH., A new concept for corrosion in hibition of magnesium: suppression of ironre-deposition,Electrochem.Commun.62(2016)5-8.

6.S.THOMAS,N.V.MEDHEKAR,G.S.FRANKEL,N.BIRBILIS, Corrosion mechanism and hydrogen evolution on Mg,Curr.Opin. SolidStateMater. Sci.19(2015)85-94.

7.A.ATRENS,G.L.SONG,F.CAO,Z.SHI,P.K.BOWEN, Advances in Mg corrosion and research suggestions, J.MagnesiumAlloys1(2013)177-200.

8.X.ZHANG, Y.-J.LI, K.ZHANG, C.-S.WANG, H.-W.LI, M.-L.MA, B. D.ZHANG,Corrosion and electrochemical behavior of Mg Y alloys in $3.5 \% \mathrm{NaCl}$ solution, Trans.NonferrousMet.Soc.China23(2013)1226-1236.

9. T. TAKENAKA, T. ONO, Y. NARAZAKI, Y. NAKA, M. KAWAKAMI, Improvement ofcorrosion resistance of magnesium metal by rare earth elements, Electrochim.Acta 53 (2007) 117-121.

10. F. ZUCCHI, V. GRASSI, A. FRIGNANI, C. MONTICELLI, G. TRABANELLI, Electrochemicalbehaviour of a magnesium alloy containing rare earth elements, J. Appl.Electrochem. 36 (2005) 195-204.

11. J. PENG, B.J. LV, X.S. TONG, Current state and prospect of research on effects ofMn on the microstructure and properties in Mg-Zn serial magnesium alloys,Light Metals 8 (2012) 55-59.

12. P.B. SRINIVASAN, J. LIANG, C. BLAWERT, M. STÖRMER, W. DIETZEL, Characterization ofcalcium containing plasma electrolytic oxidation coatings on AM50magnesium alloy, Appl. Surf. Sci. 256 (2010) 4017-4022.

13. T. TURKI, A. AISSA, C.G. BAC, F. RACHDI, M. DEBBABI, Study of mixed Ca-Znhydroxyapatite surface modified by lactic acid, Appl. Surf. Sci. 258 (2012)6759-6764.

14. H. WANG, S. ZHU, L. WANG, Y. FENG, X. MA, S. GUAN, Formation mechanism ofCa-deficient hydroxyapatite coating on Mg-Zn-Ca alloy for orthopaedicimplant, Appl. Surf. Sci. 307 (2014) 92-100.

15. L. HAN, H. HU, D.O. NORTHWOOD, N. LI, Microstructure and nano-scalemechanical behavior of Mg-Al and Mg-Al-Ca alloys, Mater. Sci. Eng., A 473(2008) 16-27.

16. F. CAO, Z. SHI, G.-L. SONG, M. LIU, A. ATRENS, Corrosion behaviour in salt sprayand in 3.5\% $\mathrm{NaCl}$ solution saturated with $\mathrm{Mg}(\mathrm{OH}) 2 \mathrm{of}$ ascast and solutionheat-treated binary Mg-X alloys: X = Mn, Sn, Ca, Zn, Al, Zr, Si, Sr, Corros. Sci.76 (2013) 60-97.

17. Y.S. JEONG, W.J. KIM, Enhancement of mechanical properties and corrosionresistance of $\mathrm{Mg}-\mathrm{Ca}$ alloys through microstructural refinement by indirectextrusion, Corros. Sci. 82 (2014) 392-403.

18. N.D. NAM, M. MATHESH, M. FORSYTH, D.S. JO, Effects of manganese additions on he corrosion behavior of an extruded Mg-Al based alloy, J. Alloys Compd. 542 (2012) 199e206.

19. J. WANG, S. HUANG, Y. LI, Y. WEI, X. XI, K. CAI, Microstructure, mechanical and bio-corrosion properties of Mn-doped Mg-Zn-Ca bulk metallic composites, Mater. Sci. Eng. C 33 (2013) 3283e3838.

20. S. SHETTY, J. NAYAK, A.N. SHETTY, Influence of sulfate ion concentration and $\mathrm{pH}$ on the corrosion of Mg-Al-Zn-Mn (GA9) magnesium alloy, J. Magnesium Alloys 3 (2015) 258e270.

21. S.LUPESCU, B. ISTRATE, C. MUNTEANU, M.G. MINCIUNA, S. FOCSANEANU AND K. EARAR 2017Characterization of Some Master Mg-X System (Ca, Mn, Zr, Y) Alloys Used in Medical Applications Rev.Chim.(Bucharest), 68, no. 6, 2018 p. $1408-1413$.

22.J.V.RAUA, I.ANTONIAC, M.FOSCA, A.DEBONIS, A.I.BLAJANC.COTRUT, V.GRAZIANI, M.CURCIO, A.CRICENTI, M.NICULESCU, M.ORTENZI, R.TEGHILD, Glass-ceramic coated Mg-Ca alloys for biomedical implant applications Materials Science and Engineering: C Volume 64, 1 July 2016, Pages 362-369.

23.D.MARECI, G.BOLAT, J.IZQUIERDO, C.CRIMU, C.MUNTEANU, I.ANTONIAC, R.M.SOUTOB, Electrochemical characteristics of bioresorbable binary $\mathrm{MgCa}$ alloys in Ringer's solution: Revealing the impact of local $\mathrm{pH}$ distributions during in-vitro dissolution, Materials Science and Engineering: C Volume 60, 1 March 2016, Pages 402-410.

24. V.RAU, I.ANTONIAC, M.FILIPESCU, C.COTRUT, M.FOSCA, L.C.NISTOR, R.BIRJEGA, M.DINESCUC, Hydroxyapatite coatings on MgCa alloy prepared by Pulsed Laser Deposition: Properties and corrosion resistance in Simulated Body Fluid, Ceramics International Volume 44, Issue 14, October 2018, Pages 16678-16687.

Manuscript received: 28.10 .2019 
